\title{
Occurrence and partial genetic characterisation of Lettuce big-vein associated virus and Mirafiori lettuce big-vein virus infecting lettuce in Jordan
}

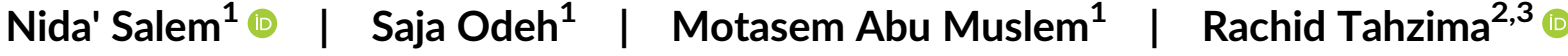 \\ ${ }^{1}$ Department of Plant Protection, School of Agriculture, The University of Jordan, Amman, Jordan \\ ${ }^{2}$ Department of Integrated and Urban Phytopathology, University of Liège (ULg) - Gembloux Agro-Bio Tech, Gembloux, Belgium \\ ${ }^{3}$ Plant Sciences Unit, Flanders Research Institute for Agriculture, Fisheries and Food (ILVO), Merelbeke, Belgium
}

Correspondence

Nida' Salem, Department of Plant Protection, School of Agriculture, The University of Jordan, Amman 11942, Jordan.

Email: n.salem@ju.edu.jo

\begin{abstract}
Lettuce big-vein disease (LBVD) is an economically damaging disease that occurs in most lettuce production areas worldwide. Several studies have associated LBVD with a complex of two viruses, Lettuce big-vein associated virus (LBVaV) and Mirafiori lettuce big-vein virus (MiLBVV). Both viruses are transmitted through soil by the zoospores of the chytridiomycete fungus Olpidium virulentus. During surveys carried out in two growing seasons from 2015 to 2016 in the main vegetable growing areas in Jordan (Jordan Valley, Jerash, and Madaba), 179 lettuce plants, 46 lettuce seedlings, and 56 weed plants were collected. RNA extraction was conducted from leaves of all samples. Associated viruses were identified using reverse transcription-polymerase chain reaction (RT-PCR) with specific primer pairs targeting part of the coat protein (CP) genes of LBVaV and MiLBVV. RT-PCR results revealed that, out of 225 lettuce samples tested, 32 (14\%) and 44 (20\%) were singly infected with LBVaV and MiLBVV, respectively, and 73 (32\%) samples were dually infected with LBVaV and MiLBVV. Overall, MiLBVV was detected in more lettuce samples (117) compared with LBVaV which was detected in 105 samples. Moreover, one sample of each weed species of Chenopodium murale and Sonchus oleraceus tested positive for MiLBVV and LBVaV, respectively. The partial nucleotide sequence of the CP genes of $L B V a V$ and MiLBVV Jordanian isolates showed similarities to other isolates available in the NCBI database ranging between $93.9-100 \%$ and $88.3-100 \%$, respectively. Nucleotide sequence comparison of the Jordanian isolates and inference from phylogenetic trees with strong support revealed well-defined sub-groups with little or no correlation with planting area or geographic origin. The occurrence of both viruses in lettuce plants was associated with the presence of resting spores and zoospores of Olpidium spp. in lettuce plants grown under field and growth chamber conditions. Lettuce plants inoculated with Olpidium spp. zoospores isolated from roots of symptomatic lettuce plants, developed LBVD-symptoms. At 60 days post-transplantation, both viruses were detected by RT-PCR in most of the plants analysed. Biological and molecular assays together with the light microscopy observations of resting spores and
\end{abstract}


zoospores of Olpidium spp., revealed the presence of LBVaV, MiLBVV, and O. virulentus in big-vein diseased lettuce plants.

\section{KEYWORDS}

(-)ssRNA virus, LBVD, LBVaV, Lactuca sativa, Ophiovirus, MiLBVV, Varicosavirus, Olpidium virulentus

\section{1 | INTRODUCTION}

Lettuce big-vein disease (LBVD) is a major damaging viral disease in lettuce (Lactuca sativa L.). It was first discovered in California (USA) (Jagger \& Chandler, 1934) and has subsequently been found in different countries around the world, including Australia, Europe, Brazil, New Zealand, Mexico, Iran, Argentina, Japan, Middle-East, and Israel (Alemzadeh \& Izadpanah, 2012; Barcala Tabarrozzi et al., 2010; Ishikawa, 2005; Maccarone, 2013; Ochoa-Martínez, AlfonsinaHernández, Sánchez-Escudero, Rodríguez-Martínez, \& Vera-Graziano,-

2014; Opatovsky, Elbaz, Tsror (Lahkim), Mordechai-Lebiush, \& Dombrovsky, 2019). LBVD reduces the marketability of the crop due to lighter or even underdeveloped heads, which leads to a low percentage of harvestable plants and eventually considerable economic losses (Verbeek, Dullemans, van Bekkum, \& van der Vlugt, 2013; Zink \& Grogan, 1954).

LBVD is currently known to be associated with a complex of two viral agents, namely, Lettuce big-vein associated virus (LBVaV, genus Varicosavirus) and Mirafiori lettuce big-vein virus (MiLBVV, genus Ophiovirus) (Lot, Campbell, Souche, Milne, \& Roggero, 2002; Navarro et al., 2004; Roggero et al., 2000; Roggero, Lot, Souche, Lenzi, \& Milne, 2003). LBVaV has non-enveloped rod-shaped particles, $18 \times 320-360 \mathrm{~nm}$ in size (Kuwata, Kubo, Yamashita, \& Doi, 1983). On the other hand, MiLBVV has a thin filamentous particle either collapsed in double-stranded forms of circular particles of $3 \mathrm{~nm}$ in diameter or as linear spiral filaments of $10 \mathrm{~nm}$ in diameter (van der Wilk, Dullemans, Verbeek, \& van den Heuvel, 2002). Both LBVaV and MiLBVV have segmented single-stranded RNA genomes. LBVaV has a bipartite genome that consists of seven open reading frames (ORFs) spanned over two negative-sense ssRNA molecules, approximately $6.8 \mathrm{~kb}$ (RNA1) and $6.1 \mathrm{~kb}$ (RNA2) in size. The LBVaV coat protein (CP) of $48 \mathrm{kDa}$ is encoded by RNA2 (King, Adams, Carsten, \& Lefkowitz, 2012; Sasaya, Ishikawa, \& Koganezawa, 2001; Sasaya, Kusaba, Ishikawa, \& Koganezawa, 2004). By contrast, the MiLBVV multipartite genome contains four ssRNAs of approximately $7.8 \mathrm{~kb}$ (RNA1), $1.7 \mathrm{~kb}$ (RNA2), $1.5 \mathrm{~kb}$ (RNA3), and $1.4 \mathrm{~kb}$ (RNA4) with seven ORFs. RNA3 encodes a $48.5 \mathrm{kDa}$ protein, which is the CP and a major component of its thin and filamentous particles (King et al., 2012; van der Wilk et al., 2002).

Both viruses have susceptible host species in the families Chenopodiaceae, Compositae, Solanaceae, and Tetragoniaceae. The main known natural host range includes lettuce, endive (Cichorium endivia L.), spiny sow thistle (Sonchus asper) and common sow thistle (Sonchus oleraceus L.) (Latham, Jones, \& McKirdy, 2004; Navarro et al., 2005).
LBVaVV and MiLBVV are naturally transmitted by the motile zoospores of the obligate root parasite Olpidium virulentus (a noncrucifer strain of O. brassicae sensu lato), a soil-borne chytridiomycete fungus (Hartwright, Hunter, \& Walsh, 2010; Koganezawa, Inoue, \& Sasaya, 2005; Maccarone, Barbetti, Sivasithamparam, \& Jones, 2010a). Resting spores of this fungus can remain dormant in the soil up to 20 years while maintaining their ability to transmit MiLBVV or LBVaV (Campbell, 1985, 1996). The association of both viral agents with $O$. virulentus could represent a serious burden in attempts to prevent disease dispersal in the field because the lack of safe and suitable soil chemicals against the fungal vector and the long life of the resting spores (Opatovsky et al., 2019). Therefore, the search for attractive alternatives for disease control such as resistant cultivars and/or the use of an engineered resistance strategy is fundamental. Hence, studies of the genetic variability in the CP genes of geographically distinct isolates of both LBVaV and MiLBVV can provide useful information towards development of sustainable control management strategies (García-Arenal, Fraile, \& Malpica, 2001).

Lettuce is a leaf vegetable cultivated on about 1,322 ha in open fields in Jordan, with 728 ha (55\% of the total) located in Jordan Valley. Two viruses have been reported to infect lettuce in Jordan; Lettuce mosaic virus (LMV) (Al-Musa \& Mansour, 1984) and Tomato spotted wilt virus (TSWV) (Salem, Mansour, \& Badwan, 2012). Recently, during comprehensive surveys carried out during two growing seasons from 2015 to 2016 in the main vegetable growing areas, severe symptoms typical to LBVD were seen on lettuce plants, and the disease has been seen in all lettuce growing regions of the country. Therefore, the aim of this work was to use biological and molecular techniques for the identification and partial characterisation of viruses infecting lettuce plants affected by LBVD. We studied the phylogenetic relationships of the $\mathrm{CP}$ genes of geographically distinct isolates including the Jordanian isolates of both LBVaV and MiLBVV. Furthermore, we determined the nucleotide sequences of the rDNAITS region of eight Jordanian Olpidium sp. isolates obtained from roots of LBVD-infected lettuce plants, and compared these to the nucleotide sequences of other Olpidium spp. isolates in the GenBank.

\section{2 | MATERIALS AND METHODS}

\subsection{Samples collection}

Lettuce leaf samples with LBVD-like symptoms were randomly collected from five commercial fields during surveys carried out in two 
growing seasons from 2015 to 2016 in the main vegetable growing areas (Jordan Valley, Jerash and Madaba) in Jordan. Three locations were sampled throughout the Jordan Valley, including Dier Alla, AbuObieda and Damia, and individual locations were sampled from Jerash and Madaba. About 30-50 lettuce plants per field were sampled by collecting one entire leaf per plant. In addition, two whole lettuce plants showing LBVD symptoms were sampled with their attached soil from the five surveyed fields in order to determine the presence of Olpidium spp. from roots. Also, around 46 lettuce seedlings were sampled from a commercial nursery in the Jordan Valley.

Furthermore, 56 plant samples of several weed species were collected from two of the surveyed lettuce fields (Dier Alla and AbuObieda) in Jordan Valley. The selected species included: Amaranthus retroflexus L. and Chenopodium murale L. (Amaranthaceae); Lactuca serriola L., Scorzonera sp. L. and S. oleraceus L. (Asteraceae); Sisymbrium irio L. (Brassicaceae); Convolvulus arvensis L. (Convolvulaceae), Hypericum triquetrifolium Turra (Hypericaceae), Malva nicaeensis All. (Malvaceae), Fumaria densiflora L. (Papaveraceae), and Urtica pilulifera L. (Urticaceae).

\subsection{Total RNA extraction and virus RT-PCR detection}

Total RNA for virus detection was extracted from all collected plant materials using SV Total RNA Isolation System (Promega, Madison, Wisconsin) following the manufacturer's instructions. RNA extracts were tested using RT-PCR with specific primers pairs targeting part of the coat protein (CP) gene of LBVaV (VP248/VP249) and MiLBVV (VP286/VP287) (Navarro et al., 2004). First-strand cDNA synthesis was carried out using Moloney murine leukaemia virus reverse transcriptase (M-MLV RT; Promega) according to manufacturer's protocol. PCR was performed, starting with an initial cycle at $94^{\circ} \mathrm{C}$ for $3 \mathrm{~min}$; followed by 35 cycles of $94^{\circ} \mathrm{C}$ for $30 \mathrm{~s}, 62^{\circ} \mathrm{C}$ for $30 \mathrm{~s}, 72^{\circ} \mathrm{C}$ for $40 \mathrm{~s}$ and a final cycle at $72^{\circ} \mathrm{C}$ for $10 \mathrm{~min}$. Amplicons of the expected size were excised from the gel, purified using a Zymoclean gel DNA recovery kit (Zymo Research Corp., Irvine, California) and cloned into pGEM-T Easy Vector (Promega). Two clones from each sample were sequenced in both directions by Sanger sequencing (Macrogen, Seoul, Korea). All sequences were deposited in the GenBank with their respective accession numbers (Table S1; Aleandri et al., 2014; Herrera-Vásquez et al., 2010; Kawazu et al., 2003; Sanches et al., 2008; Sasaya et al., 2005).

\section{3 | Virus transmission}

Roots of lettuce plants with typical LBVD symptoms that tested positive by RT-PCR for LBVaV and MiLBVV were inspected using light microscopy to verify infection with Olpidium sp. (Rochon, 2009). If Olpidium-infection was confirmed in the roots, then roots were used for virus transmission by substrate inoculation with viruliferous zoospores of Olpidium sp. under controlled conditions (Bos \& Huijberts, 1990). Inoculum was prepared by macerating around $50 \mathrm{~g}$ of roots from infected lettuce with LBVaV and MiLBVV in a Waring blender with $200 \mathrm{~mL}$ sterile distilled water for $5 \mathrm{~min}$ at $300 \mathrm{rpm}$ and filtered through 250 and $106 \mu \mathrm{M}$ mesh sieve to remove soil clods prior to processing. The filtrate was centrifuged twice at $1700 \mathrm{rpm}$ for $5 \mathrm{~min}$, subsequently the precipitate was suspended in $25 \mathrm{~mL}$ sterile distilled water, vortexed for 30 seconds to make the inoculum homogenous. Around $25 \mathrm{~mL}$ of a zoospore suspension were applied to 20 two-week-old lettuce cv. "Parris Island Cos." seedlings transplanted in pots containing a pre-sterilised soil. Plants were kept in a plant growth chamber with a 14-hr light/10-hr dark cycle at 20 $\pm 2^{\circ} \mathrm{C}$. Two months after inoculation, virus infections were evaluated by observation of symptoms and virus detection by RT-PCR. Fungus infection was microscopically assessed in lettuce roots. Five $1-\mathrm{cm}$ long slices of roots per plant were randomly taken and stained with methylene blue and visualised by light microscopy. Furthermore, zoospores were collected from five plants infected with LBVaV or MiLBVV alone, or both in coinfection, and used for further groups of 20 lettuce seedlings. The transfer was repeated eight times.

\subsection{DNA extraction and Olpidium spp. detection in roots}

From each field, two whole lettuce plants with attached soil were sampled. Olpidium spp. presence was assayed in roots after DNA extraction, by using PCR. To extract DNA from Olpidium spp., the suspension of the resting spores and zoospores prepared as above (Section 2.3) were centrifuged at $14000 \mathrm{rpm}$ for $5 \mathrm{~min}$ at $4^{\circ} \mathrm{C}$, the precipitate was placed in $400 \mu \mathrm{L}$ buffer AP1 (included in the DNeasy Plant Mini Kit; Qiagen Inc., Valencia, California) and vigorously vortexed for $30 \mathrm{~s}$. DNA extraction followed according to the manufacturer's instructions. Extracted DNA was dissolved in $200 \mu \mathrm{L}$ nuclease free water and stored at $-20^{\circ} \mathrm{C}$ until use.

DNA extracts were tested by PCR using species-specific forward primers OLPborF, OLPbraF, and OLPvirF for Olpidium bornovanus, Olpidium brassicae, and Olpidium virulentus, respectively and the reverse primer OLPR (Herrera-Vásquez, Cebrián, Alfaro-Fernández, Córdoba-Sellés, \& Jordá, 2009), designed to target the rDNA-ITS region. DNA from the 10 samples produced only a single amplicon of approximately 579 bp with primer set OLPvirF and OLPR. To confirm the identity of the Olpidium sp., eight amplified PCR products were purified using DNA Clean \& Concentrator kit (Zymo Research Corp.), cloned and sequenced as mentioned in Section 2.2. The sequences obtained for $\mathrm{O}$. virulentus have been submitted to the NCBI database under accession numbers MN238816-17, and MN699436-41 (Table S1; Aleandri et al., 2014; Herrera-Vásquez et al., 2010; Kawazu et al., 2003; Sanches et al., 2008; Sasaya et al., 2005).

\subsection{Sequencing and phylogenetic analysis}

The locality, nomenclature and GenBank accession number of diverse isolates of LBVaV, MiLBVV, and Olpidium spp. under study are 
summarised in Table S1. The nucleotide sequences were compared with sequences available from the NCBI database using BLASTn program in GenBank (https://blast.ncbi.nlm.nih.gov/Blast.cgi). Sequences from different hosts and origins were aligned with ClustalX (Thompson, Gibson, Plewniak, Jeanmougin, \& Higgins, 1997), then visualised and analysed with the Molecular Evolutionary Genetics Analysis Version $X$ (MEGA X) software (Kumar, Stecher, Li, Knyaz, \& Tamura, 2018). Phylogenetic trees were constructed using the Maximum Likelihood (ML) method with 1,000 bootstrap replicates. The model with the lowest BIC value was chosen to construct the ML trees.

\section{RESULTS}

\section{1 | Prevalence and detection of LBVaV and MiLBVV in lettuce fields and nursery}

Field symptoms in the collected samples ranged from slight swelling to pronounced thickening of the main veins, severe leaf crinkling "bumpy," stunting and reduction in growth (Figure 1). Symptoms were more pronounced during the cool season (December, January, and February).

RT-PCR generated expected fragments of 296 and $469 \mathrm{bp}$ in size indicating the presence of LBVaV and MiLBVV, respectively (Figure 2).
Out of the 225 lettuce samples (plants and seedlings) tested, the presence of LBVaV or MiLBVV in single or mixed infections was revealed in 149 samples. Of the total number of leaf samples that tested positive, 32 (14\%) and 44 (20\%) lettuce samples were singly infected with LBVaV and MiLBVV, respectively, and 73 (32\%) samples were dually infected with LBVaV and MiLBVV (Table 1). Overall, MiLBVV was detected in more lettuce samples (117) compared with LBVaV which was detected in 105 samples, indicating higher prevalence of MiLBV in the lettuce-producing regions surveyed in Jordan, irrespective of the presence or absence of LBVaV. Among the three surveyed regions, levels of LBVD infection in the collected samples ranged from 58 to $69 \%$, with samples of Madaba and Jerash, showing the lowest and highest levels of infection, respectively.

This is corroborating our field observations of the LBVD infection incidence where severe LBVD symptoms reached $75 \%$ in Jerash. Interestingly, MiLBVV was detected in all positive collected material from that area, whether in single or mixed infection (Table 1). On the other hand, all tested plants with severe symptoms from Jerash were infected by both LBVaV and MiLBVV.

Importantly, among the collected lettuce samples, 46 seedlings were sampled from a commercial nursery in the Jordan Valley and tested by RT-PCR. About 12 (26\%) and eight (17\%) lettuce samples were singly infected with LBVaV and MiLBVV, respectively. Coinfections with LBVaV and MiLBVV were observed in eight (17\%) samples. Moreover, a total of 56 samples corresponding to
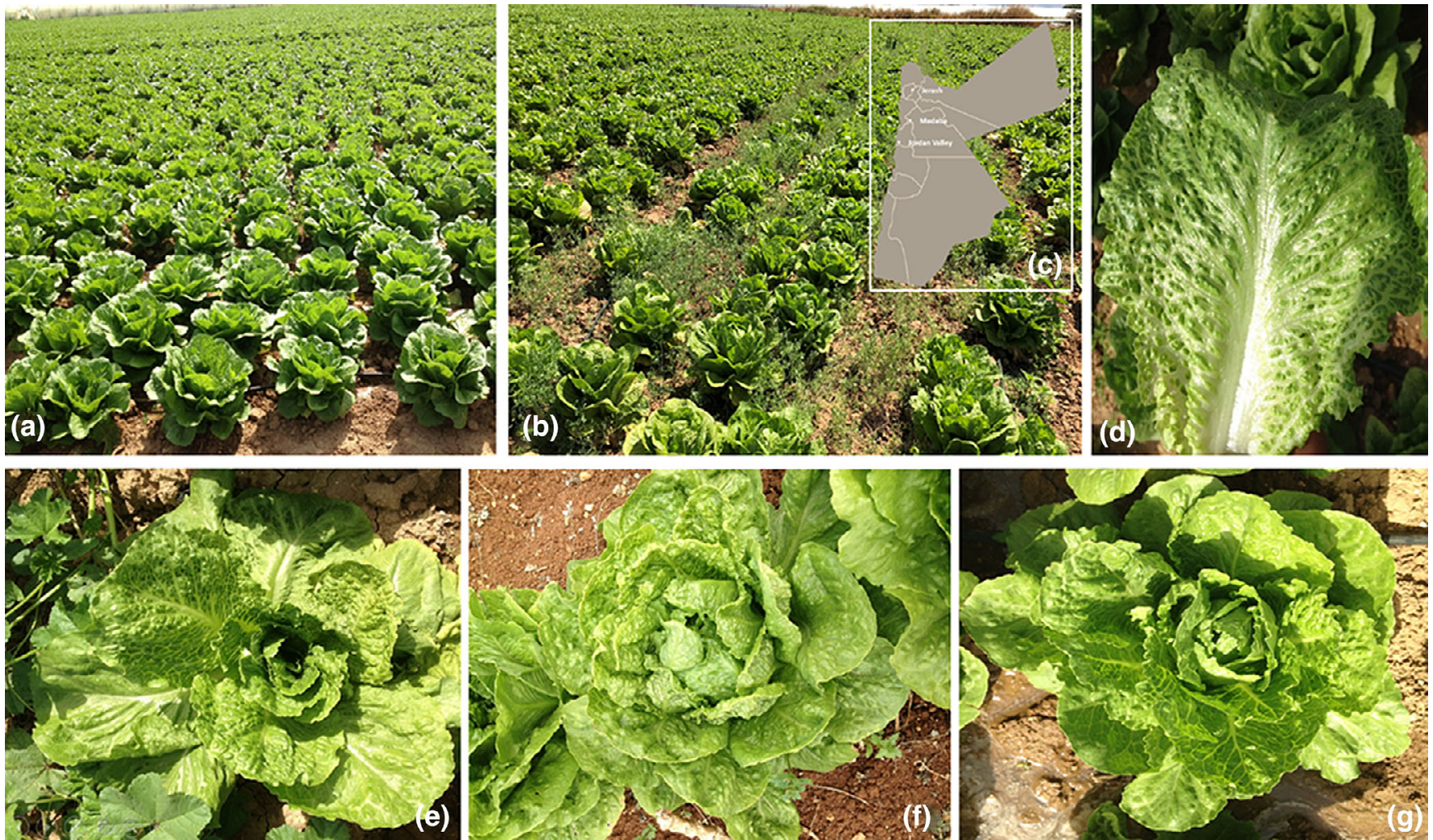

FIGURE 1 Lettuce fields ( $a$ and $b$ ) and surveyed locations in Jordan (c). Symptomatic lettuce leaf showing LBVD clear symptoms (d). Lettuce crops affected with LBVaV and MiLBVV (e), LBVaV (f), and MiLBVV (g). LBVD, lettuce big-vein disease; LBVaV, Lettuce big-vein associated virus; MiLBVV, Mirafiori lettuce big-vein virus 


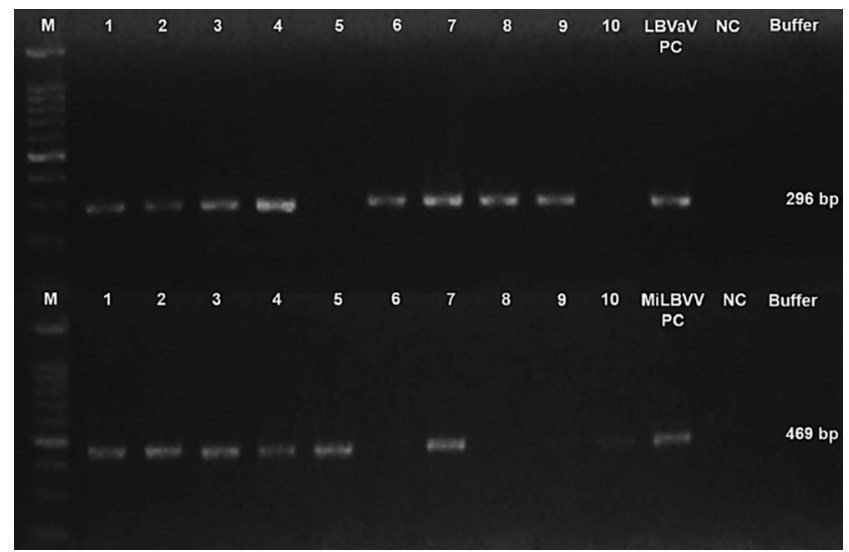

FIGURE 2 Agarose gel analysis (1.5\%) resulting from RT-PCR detection of the presence of LBVaV (upper lanes 1-10) and MiLBVV (lower lanes 1-10) in 10 samples of lettuce with lettuce big vein disease-like symptoms from Jordan. NC is a negative healthy lettuce plant control. Specific size of amplicon is shown on the right. Lane $M$ represents a 100 bp DNA ladder (GeneDirex). LBVaV, Lettuce bigvein associated virus; MiLBVV, Mirafiori lettuce big-vein virus; RT$\mathrm{PCR}$, reverse transcription-polymerase chain reaction
TABLE 2 Detection of LBVaV and MiLBVV by RT-PCR in weeds collected from Jordan Valley during field surveys 2015-2016

\begin{tabular}{llll} 
Weed species & Family & LBVaV & MiLBV \\
\hline Amaranthus retroflexus L. & Amaranthaceae & $0 / 17$ & $0 / 17$ \\
\hline Chenopodium murale L. & Amaranthaceae & $0 / 2$ & $1 / 2$ \\
\hline Lactuca serriola L. & Asteraceae & $0 / 3$ & $0 / 3$ \\
\hline Scorzonera sp. L. & Asteraceae & $0 / 1$ & $0 / 1$ \\
\hline Sonchus oleraceus L. & Asteraceae & $1 / 2$ & $0 / 2$ \\
\hline Sisymbrium irio L. & Brassicaceae & $0 / 1$ & $0 / 1$ \\
\hline Convolvulus arvensis L. & Convolvulaceae & $0 / 1$ & $0 / 1$ \\
\hline Hypericum triquetrifolium & Hypericaceae & $0 / 1$ & $0 / 1$ \\
\hline Turra & & & \\
Malva nicaeensis All. & Malvaceae & $0 / 4$ & $0 / 4$ \\
\hline Fumaria densiflora L. & Papaverceae & $0 / 22$ & $0 / 22$ \\
Urtica pilulifera L. & Urticaceae & $0 / 2$ & $0 / 2$
\end{tabular}

Abbreviations: LBVaV, Lettuce big-vein associated virus; MiLBVV, Mirafiori lettuce big-vein virus; RT-PCR, reverse transcription-polymerase chain reaction.

TABLE 1 Detection of LBVaV and MiLBVV by RT-PCR in lettuce collected from three lettuce-producing regions in Jordan where big-vein disease was a serious problem, during field surveys in 2015-2016

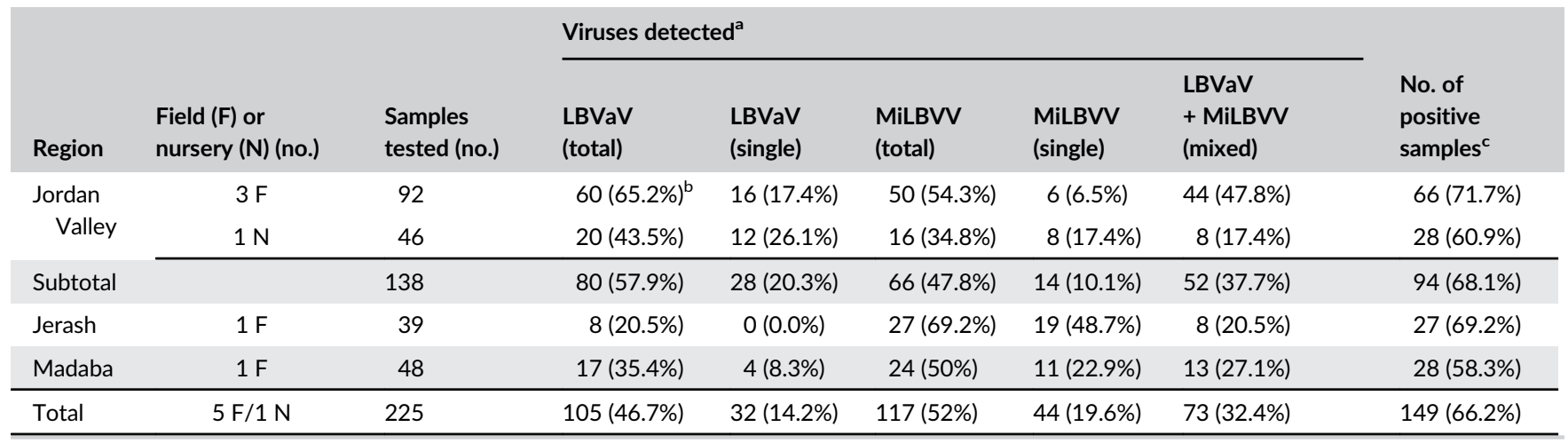

Abbreviations: LBVaV, Lettuce big-vein associated virus; MiLBVV, Mirafiori lettuce big-vein virus; RT-PCR, reverse transcription-polymerase chain reaction.

aLettuce plants were tested for LBVaV and MiLBVV infection by RT-PCR.

${ }^{b}$ The number of plant samples that tested positive by RT_PCR for each particular virus over the total number of tested plant samples $\times 100 \%$.

${ }^{\mathrm{C}}$ The number of plant samples that tested positive by RT-PCR for one virus (single infection) or more than one virus (mixed infection).

11 different plant species belonging to eight families were tested for the presence of LBVaV and MiLBVV. Only one sample of each C. murale and S. oleraceus tested positive for MiLBVV and LBVaV, respectively (Table 2). Only single LBVaV and MiLBVV infection was observed in the infected asymptomatic plants. In contrast, none of the collected weed species or those observed in the field exhibited any type of symptoms.

\section{2 | Vector transmission}

Fungal structures within the cells of root segments stained with methylene blue dye were visualised using light microscopy. Resting spores and zoospores were clearly observed within the root cells of the naturally infected lettuce plants collected from the fields and in roots of lettuce seedlings cv. "Parris Island Cos" used in the virus transmission test. After 50-60 days post-transplantation, lettuce plants cv. "Parris Island Cos." developed big-vein symptoms when they were inoculated with Olpidium spp. zoospores isolated from roots of symptomatic lettuce plants. Furthermore, the fungus was present in all analysed samples and was shown to foster transmission of both viruses. At 60 days post-transplantation, LBVaV and MiLBVV presence were confirmed by RT-PCR in 20 lettuce plants. All lettuce plants showed the presence of at least one of the associated big-vein viruses but six samples clearly showed big-vein symptoms. LBVaV and MiLBVV infected 18 and six lettuce plants, respectively. Mixed infection was observed 
in four samples. Mixed infections were observed in all symptomatic plants, except two plants in which only MiLBVV was detected (Figure 3a,b).

\section{3 | Detection of Olpidium spp. in root samples}

Lettuce root samples confirmed to be infected by Olpidium spp. using microscopy could be identified at species level using PCR. Only $O$ virulentus was found in the lettuce roots of field infected samples from all surveyed fields (Figure 4). Expected PCR products of approximately $579 \mathrm{bp}$ were obtained from the amplified genomic DNA of each sample using the primers OLPvirF and OLPR.

The rDNA-ITS nucleotide sequences obtained in this work for eight Olpidium sp. isolates were compared with available sequences from the $\mathrm{NCBI}$ database and accurately matched $\mathrm{O}$. virulentus $\mathrm{NCBI}$ entries as expected. The nucleotide sequence identities of the eight Olpidium sp. Jordanian isolates ranged between 98.9 and 100\%. Phylogenetic analysis was carried out including eight rDNA-ITS nucleotide sequences

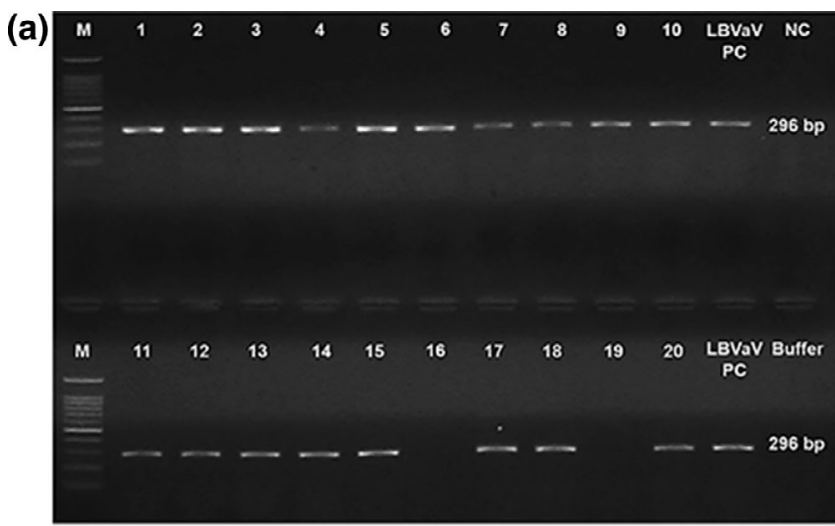

(b)

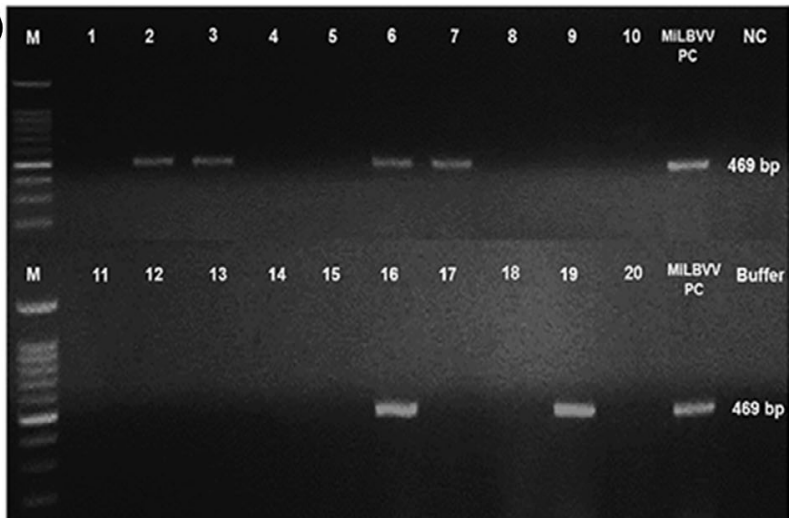

FIGURE 3 Agarose gel analysis (1.5\%) resulting from RT-PCR detection of the presence of LBVaV (a) and MiLBVV (b) in 20 samples of lettuce plant (lanes 1-20) from virus transmission experiments. NC is a negative healthy lettuce plant control. Specific size of amplicon is shown on the right. Lane $M$ represents a 100 bp DNA ladder (GeneDirex). LBVaV, Lettuce big-vein associated virus; MiLBVV, Mirafiori lettuce big-vein virus; RT-PCR, reverse transcriptionpolymerase chain reaction

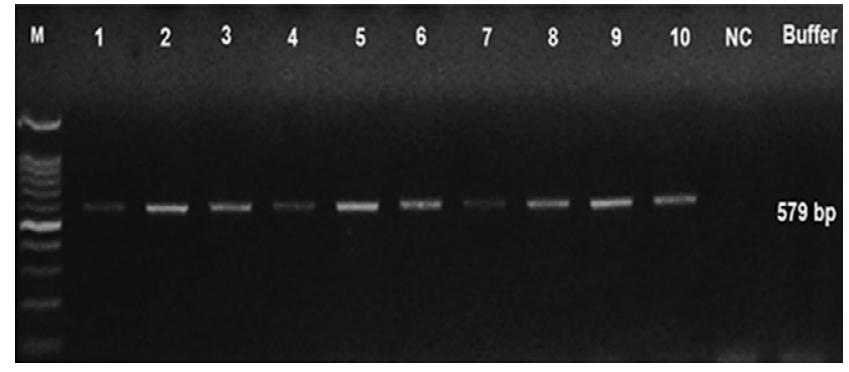

FIG URE 4 Agarose gel (1.5\%) resulting from PCR of Olpidium spp. from root of lettuce plants. Root of naturally symptomatic lettuce plants collected from LBVD-affected fields (lanes 1-10). NC is root of healthy lettuce plant. Specific size of amplicon (579 bp) corresponding to Olpidium virulentus is shown on the right. Lane $M$ represents a 100 bp DNA ladder (GeneDirex). LBVD, lettuce big-vein disease; PCR, polymerase chain reaction

determined here and 27 sequences from the NCBI database. Two main groups could be identified; group I contained $O$. virulentus sequences from Turkey, Japan, Australia, Spain, Mexico, United Kingdom, Guatemala, Italy and Jordan, with nucleotide identity for sequences within group ranged between 93.1 and 100\%, and group II contained O. brassicae sequences from Japan and United Kingdom with nucleotide identity ranging between 96.2 and $99.8 \%$ (Figure 5). Interestingly, $\mathrm{O}$. virulentus isolates did not group according to their host or their geographical locations from which they were isolated.

\section{4 | Sequence diversity and phylogenetic analysis of the CP genes of LBVaV and MiLBVV isolates}

The determination of the genetic diversity and relationship of LBVaV and MiLBVV was based on the analysis of the CP genomic region. All sequences obtained in this study were compared against the homologous CP genomic region of a representative set of $\mathrm{LBVaV}$ and MiLBVV isolates available in GenBank.

For this purpose, $12 \mathrm{LBVaV} \mathrm{CP}$ nucleotide sequences generated in this study were aligned and deposited in the GenBank database under the accession numbers indicated in Table S1. Calculated pairwise nucleotide identities between the 11 Jordanian isolates from lettuce ranged between 97.6 and $\mathbf{9 9 . 7 \%}$. Similarly, the identity of LBVaV in S. oleraceus was established based on sequence analysis of the CP gene. The percentage of nucleotide identity between S. oleraceus and other 11 Jordanian isolates ranged from 98.3 to 99.7\%. When LBVaV CP sequences from the NCBI database (Table S1) were included in our analysis, percentages of nucleotide identity varied between 93.9 and $100 \%$.

Phylogenetic analysis using the CP sequences of the 12 LBVaV isolates under study from Jordan and those available on GenBank revealed the existence of two main groups (Figure 6). Group I contained Australian, Jordanian, European, and Israeli sequences and group II contained Chinese and Japanese sequences. The percentages of nucleotide identity for sequences within groups I and II ranged 


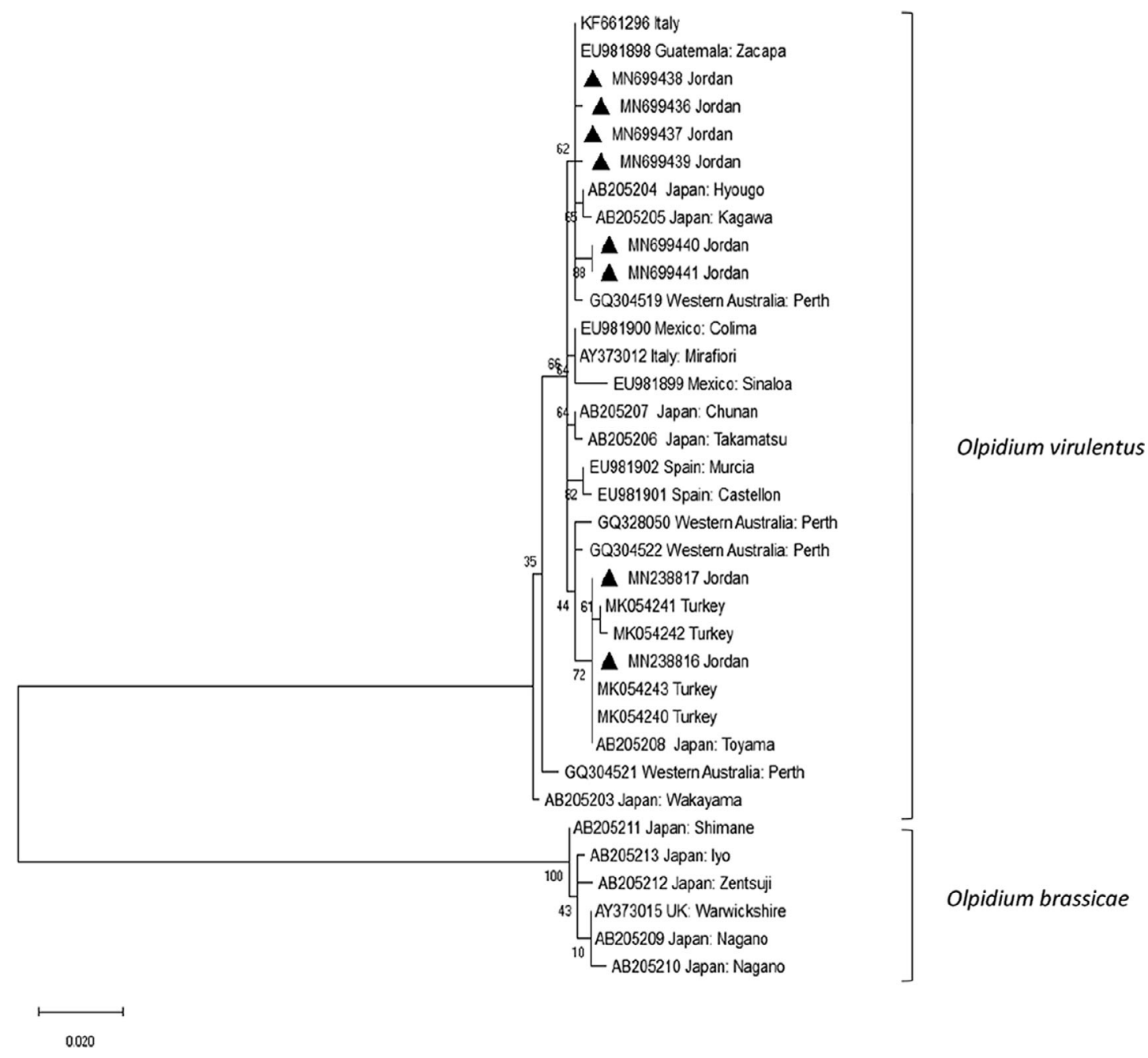

FIGURE 5 Maximum likelihood phylogenetic tree of 1,000 bootstrap replicates obtained from distance matrix (Tamura 3-parameter model) with MEGA X from nucleotide sequences of the rDNA-ITS region of eight Olpidium virulentus isolates from Jordan (indicated with a triangle). Sequences from other Olpidium isolates obtained from the NCBI database were included with their GenBank accession numbers and origin. Numbers at nodes indicate bootstrap values. The scale bar represents a genetic distance of 0.02

between $93.6-100 \%$ and $99.3-100 \%$, respectively. All isolates from Jordan were more closely related to the European isolates of LBVaV and one Israeli isolate than to LBVaV isolates from Australia.

The nucleotide sequence identities of the 10 MiLBVV Jordanian isolates ranged between 96.9 and 100\%. When MiLBVV CP sequences from the $\mathrm{NCBI}$ database (Table S1) were included in the analysis, the nucleotide sequence identities of all $77 \mathrm{CPs}$ were ranged between 88.3 and $100 \%$. Phylogenetic analysis of the CP gene of MiLBVV isolates showed the existence of two main groups (Figure 7). The percentages of nucleotide identity for sequences within groups I and II varied between $98.1-100 \%$ and $95.8-100 \%$, respectively. Group II contained only Spanish sequences from Murcia and Almería. The topology of the constructed phylogenetic tree revealed no clear relationship between geography and position in the tree in group I. Jordanian isolates were grouped together in group I with sequences from Turkey, Iran, Germany, Italy, Argentina, Brazil, Australia, Netherlands, Japan, Denmark, United Kingdom, and Spain.
The comparative sequence analysis in this study also showed that the CP fragment among sequences of Jordanian LBVaV isolates is more conserved than those of MiLBVV sequences. Overall, the high sequence identities shared by CPs of the 12 LBVaV and 10 MiLBVV isolates from Jordan further support that occurrence of the fungal vector and both viruses in Jordan may be a plausible outcome from a single introduction event.

\section{4 | DISCUSSION}

The present investigation examined the prevalence and genetic diversity of LBVaV and MiLBVV, associated with LBVD. This study revealed that LBVD is a commonly established problem in commercial lettuce producing regions in Jordan as a probable virus complex with high incidence partly due to permissive conditions such as intensive lettuce cultivation, use of nursery-grown planting materials, and 


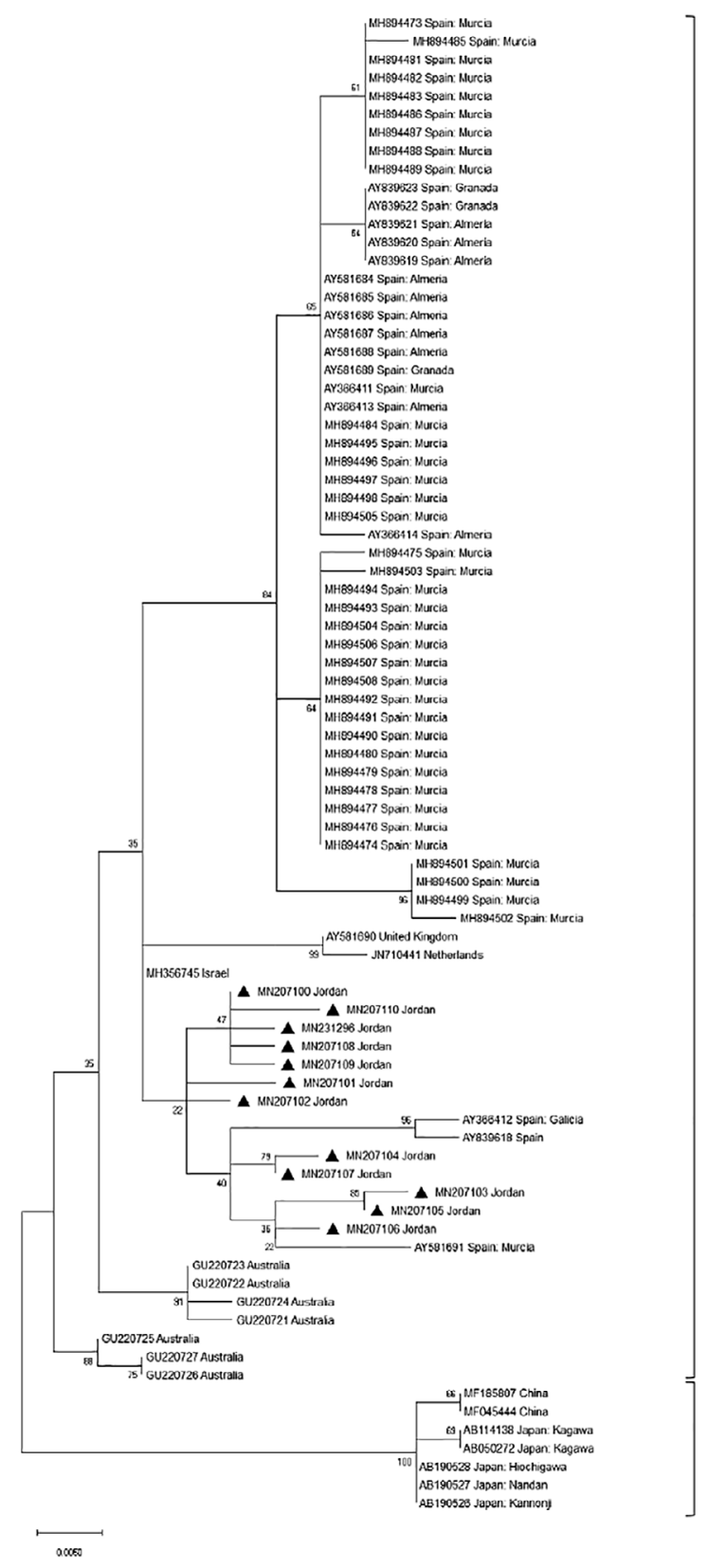

FIGURE 6 Maximum likelihood phylogenetic tree of 1,000 bootstrap replicates obtained from distance matrix (Kimura 2-parameter model) with MEGA $X$ from nucleotide sequences coding for CP of $82 \mathrm{LBV}$ aV isolates. Sequences from Jordan are indicated with a triangle. Sequences from the NCBI database were included with their GenBank accession numbers and origin. Numbers at nodes indicate bootstrap values. The scale bar represents a genetic distance of 0.005 . LBVaV, lettuce big-vein associated virus

irrigated land that is contaminated with LBVaV, MiLBVV, and $O$. virulentus. Symptoms were more pronounced during the cool season (December, January, and February). Generally, symptom expression of LBVD is most observable at low temperatures and light intensities (Lot et al., 2002; Walsh, 1994; Westerlund, Campbell, \& Grogan, 1978). Maekawa et al. (2004) demonstrated that a decrease in growth temperature from $27^{\circ} \mathrm{C}$ to $18^{\circ} \mathrm{C}$ facilitated the appearance of big-vein symptoms and the detection of MiLBVV in the leaves.

The RT-PCR was successfully used here to achieve efficient detection of both viruses associated with LBVD in naturally infected lettuce samples collected from different production areas (Navarro et al., 2004). RT-PCR results showed that LBVD was predominantly associated with two viruses, LBVaV and MiLBVV, which confirms previous results in literature (Alemzadeh \& Izadpanah, 2012; BernalVicente et al., 2018; Navarro et al., 2004; Navarro, Botella, et al., 2005; Roggero et al., 2000). Although, some other studies have shown that lettuce plants displaying big-vein symptoms are infected only by MiLBVV (Roggero et al., 2003; Verbeek et al., 2013).

Both LBVaV and MiLBVV were detected in $43.4 \%$ and $34.7 \%$, respectively, of lettuce seedlings collected from a commercial nursery in the Jordan Valley. This could have a very significant epidemiological impact on the spread of LBVD in commercial lettuce growing fields. Latham et al. (2004) showed that early infection of lettuce seedlings with LBVaV and MiLBVV generated more severe symptoms and yield loss than infections occurring later once the seedlings have been transferred to the field. Therefore, anticipation of further LBVD outbreaks at early production stages in commercial seedling nurseries may help to ensure better yields (Maccarone, 2013).

Weeds may play an essential role in the long-term dissemination of the vector $O$. virulentus along with both associated viruses (Maccarone, 2009; Navarro et al., 2004). In this work, the potential role of some abundant occurring weed species in lettuce crops as host plants for LBVaV and MiLBVV was investigated using RT-PCR. The results showed $C$. murale and $S$. oleraceus as the only species infected with MiLBVV and LBVaV, respectively, among those analysed (Table 2). C. murale and S. oleraceus are common weed species in agricultural regions of Jordan Valley and they might be involved in the spread of LBVD. Eventually, management of these weeds could help mitigate inoculum levels in soil and subsequent spread of LBVD in the field. The identity LBVaV in S. oleraceus was established based on sequence analysis of the CP gene (Figure 6). The high nucleotide sequence identity between LBVaV isolates from lettuce and S. oleraceus in addition to the close phylogenetic relationship among Jordanian lettuce and weed isolates, suggests the ability of LBVaV to infect both lettuce and $S$. oleraceus, as natural hosts.

Transmission of lettuce big vein associated viruses with Olpidium spp. is well understood (Campbell, 1996; Lot et al., 2002). In the present study, Olpidium resting spores were detected in the lettuce rhizosphere both under the field conditions and in our growth chamber transmission assay. This fungus has never been isolated from the roots of plants in Jordan. To our knowledge, this is the first study reporting the identification at the species level of Olpidium sp. $(O$. virulentus) in Jordan. The widespread occurrence of LBVaV and MiLBVV in Jordan is undoubtedly correlated with the presence of Olpidium sp. in the three surveyed regions. This study showed that $O$. virulentus was the only fungal species associated with LBVD-infected lettuce plants collected from five fields in Jordan in which detection of LBVaV and MiLBVV, in single or mixed infection was confirmed. 


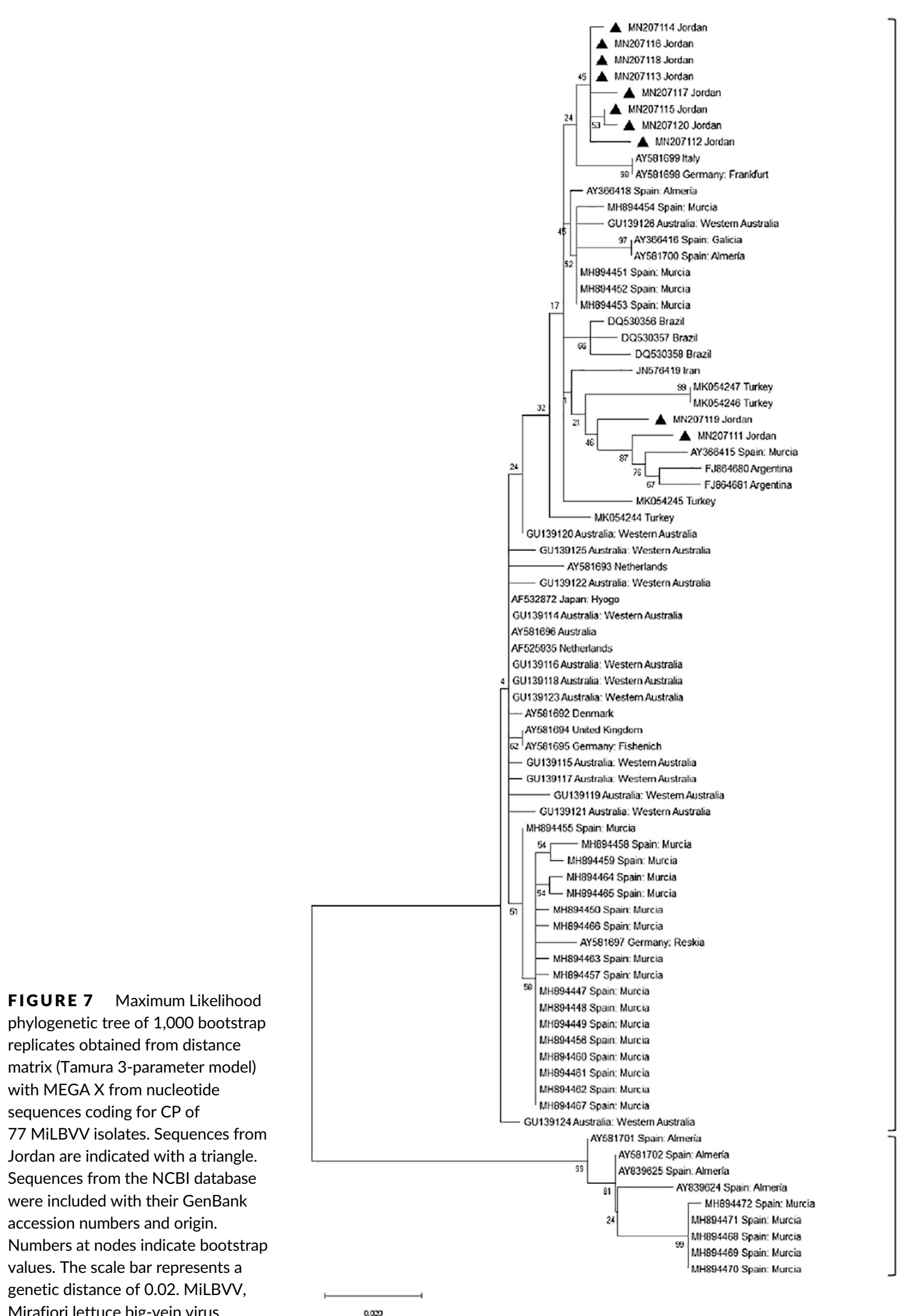


The observed association of $O$. virulentus with the two viruses is consistent with previous research showing this species, rather than O. brassicae, as the main vector of MiLBVV, Tobacco stunt virus (TStV strain), and LBVaV infecting lettuce (Sasaya \& Koganezawa, 2006). This excludes also $O$. brassicae infecting lettuce in Jordan as previously reported (Hartwright et al., 2010; Koganezawa et al., 2005; Sasaya \& Koganezawa, 2006).

In our virus transmission experiments, the higher presence of LBVaV $(18 / 20)$ in the inoculated lettuce plants compared to MiLBVV $(6 / 20)$ can be attributed to the fact that LBVaV infection develops faster than MiLBVV infection, and that LBVaV replicated over a wider range of temperatures than MiLBVV as previously reported by Maekawa et al. (2004). Recently, Bernal-Vicente et al. (2018) showed that LBVaV accumulated to higher levels in contrast to MiLBVV in different types of plant tissues (leaves, roots, symptomatic, asymptomatic). Therefore, lack of sensitivity of the RT-PCR assay used here may have hindered the detection of MiLBVV in low concentrations in these lettuce plants. Accordingly, detection of MiLBVV may require higher sensitivity in comparison to LBVaV. Consequently, the use of alternative more sensitive method as reverse transcription-real time quantitative PCR (qRT-PCR) may resolve this constraint.

LBVD is difficult to control because both LBVaV and MiLBVV can survive from one crop to another in the thick cell-walled persisting spores of O. virulentus (Campbell, 1996). Therefore, studies on the genetic diversity are justified as an essential prerequisite to be considered in order to design sound disease control strategies (García-Arenal et al., 2001). In this study, the genetic variability in the CP genes of LBVaV and MiLBVV from diverse geographical origins available in databases was investigated.

The deduced relationships from our phylogenetic analyses of the LBVaV sequences indicated the presence of two main groups (I and II). Group I contained European (Spain, United Kingdom, Netherlands), Australian, Jordanian, and Israeli isolates, while group II contained only Asian (Japan and China) isolates, in agreement with previous analysis (Maccarone, Barbetti, Sivasithamparam, \& Jones, 2010b) (Figure 6).

Moreover, analysis of the MiLBVV sequences revealed two main groups (I, II). Group II contained only isolates from Spain, while group I contained isolates from different geographic origins (Figure 7). Navarro, Torok, Vetten, and Pallas (2005) also reported the existence of two major groups which were referred to as subgroups $A$ and B. No correlation could be inferred between the geographic origin of the sequence and its position in the phylogenetic trees. These results are consistent with Bernal-Vicente et al. (2018) work in which regular long-distance movement of MiLBVV-infective materials was suggested. Diversity of the LBVaV isolates analysed in this study was lower than that of the MiLBVV isolates reflecting its probable recent introduction as previously proposed (Maccarone et al., 2010b; Navarro, Torok, et al., 2005).

In conclusion, both MiLBVV and LBVaV appear to be widespread in Jordan which may economically impact lettuce production. The occurrence of both viruses is correlated with the presence of $O$. virulentus. The present study confirmed the identity and phylogenetic relationships of LBVaV, MiLBVV, and O. virulentus isolates, as well as the role of the vector $O$. virulentus in the transmission of LBVD. Currently, in our lab, important aspects of seed transmission of LBVD in lettuce seeds are subject to further investigation.

\section{ORCID}

Nida' Salem (D) https://orcid.org/0000-0003-3778-2213

Rachid Tahzima (D) https://orcid.org/0000-0002-0115-8366

\section{REFERENCES}

Aleandri, M. P., Martignoni, D., \& Reda, R. (2014). First report of Olpidium bornovanus and O. virulentus on melon in Italy. Plant Disease, 98, 997.

Alemzadeh, E., \& Izadpanah, K. (2012). Occurrence and partial characterization of Lettuce big-vein associated virus and Mirafiori lettuce big-vein virus in lettuce in Iran. Indian Journal of Virology, 23, 354-358.

Al-Musa, A., \& Mansour, A. (1984). Occurrence and incidence of lettuce mosaic virus in Jordan. Phytopathologia Mediterranea, 23, 57-59.

Barcala Tabarrozzi, A. E., Peňa, E. J., Dal Bo, E., Robles Luna, G., Reyes, C. A., \& Garcia, M. L. (2010). Identification of Mirafiori lettuce big-vein virus and Lettuce big-vein associated virus infecting Lactuca sativa with symptoms of lettuce big-vein disease in Argentina. Plant Pathology, 59, 1160-1161.

Bernal-Vicente, A., Donaire, L., Torre, C., Gomez-Aix, C., SanchezPina, M. A., Juarez, M., ... Aranda, M. A. (2018). Small RNA-Seq to characterize viruses responsible of lettuce big vein disease in Spain. Frontiers in Microbiology, 9, 3188. https://doi.org/10.3389/fmicb. 2018.03188

Bos, L., \& Huijberts, N. (1990). Screening for resistance to big-vein disease of lettuce (Lactuca sativa). Crop Protection, 9, 446-452.

Campbell, R. N. (1985). Longevity of Olpidium brassicae in air-dry soil and the persistence of the lettuce big-vein agent. Canadian Journal of Botany, 63, 2288-2289.

Campbell, R. N. (1996). Fungal transmission of plant viruses. Annual Review of Phytopathology, 34, 87-108.

García-Arenal, F., Fraile, A., \& Malpica, J. M. (2001). Variability and genetic structure of plant virus populations. Annual of Review Phytopathology, 39, 157-186.

Hartwright, L. M., Hunter, P. J., \& Walsh, J. A. (2010). A comparison of Olpidium isolates from a range of host plants using internal transcribed spacer sequence analysis and host range studies. Fungal Biology, 114, 26-33.

Herrera-Vásquez, J. A., Cebrián, M., Alfaro-Fernández, A., Córdoba-Sellés, M del C., \& Jordá, C. (2009). Multiplex PCR assay for the simultaneous detection and differentiation of Olpidium bornovanus, $O$. brassicae, and O. virulentus. Mycological Research, 113, 602-610.

Herrera-Vásquez, J. A., Córdoba-Sellés, M. del C., Cebrián, M., Rosselló, J. A., Alfaro-Fernández, A., \& Jordá, C. (2010). Genetic diversity of Melon necrotic spot virus and Olpidium isolates from different origins. Plant Pathology, 59, 240-251.

Ishikawa, K. (2005). Detection of Mirafiori lettuce virus by ELISA. Plant Protection, 59, 261-264.

Jagger, I. C., \& Chandler, N. (1934). Big vein, a disease of lettuce. Phytopathology, 24, 1253-1256.

Kawazu, Y., Sasaya, T., Morikawa, T., Sugiyama, K., \& Natsuaki, T. (2003). Nucleotide sequence of the coat protein gene of Mirafiori lettuce virus. Journal of General Plant Pathology, 69, 55-60.

King, A. M. Q., Adams, M. J., Carsten, E. B., \& Lefkowitz, E. J. (2012). Virus taxonomy: Classification and nomenclature of viruses. In Ninth report of the international committee on taxonomy of viruses. London: Elsevier.

Koganezawa, H., Inoue, H., \& Sasaya, J. (2005). Host specificity and multiplication of eight isolates of Olpidium brassicae sensu lato and its related Olpidium spp. Bulletin of the National Agricultural Research Center for Western Region, 4, 39-40. 
Kumar, S., Stecher, G., Li, M., Knyaz, C., \& Tamura, K. (2018). MEGA X: Molecular evolutionary genetics analysis across computing platforms. Molecular Biology and Evolution, 35, 1547-1549.

Kuwata, S., Kubo, S., Yamashita, S., \& Doi, Y. (1983). Rod-shaped particles, a probable entity of Lettuce big-vein virus. Annals of Phytopathological Society of Japan, 49, 246-251.

Latham, L. J., Jones, R. A. C., \& McKirdy, S. J. (2004). Lettuce big-vein disease: Sources, patterns of spread, and losses. Australian Journal of Agricultural Research, 55, 125-130.

Lot, H., Campbell, R. N., Souche, S., Milne, R. G., \& Roggero, P. (2002). Transmission by Olpidium brassicae of Mirafiori lettuce virus and Lettuce big-vein virus, and their roles in lettuce big-vein etiology. Phytopathology, 92, 288-293.

Maccarone, L.D. (2009). Molecular genetic characterisation of Mirafiori lettuce big-vein virus and Lettuce big-vein associated virus and their vector Olpidium virulentus associated with lettuce big-vein disease and the determination of their inoculum sources in Western Australia. (Ph.D. thesis). University of Western Australia, Perth, WA.

Maccarone, L. D. (2013). Relationships between the pathogen Olpidium virulentus and viruses associated with lettuce big-vein disease. Plant Disease, 97, 700-707.

Maccarone, L. D., Barbetti, M. J., Sivasithamparam, K., \& Jones, R. A. C. (2010a). Molecular genetic characterization of Olpidium virulentus isolates associated with big-vein diseased lettuce plants. Plant Disease, 94, 563-569.

Maccarone, L. D., Barbetti, M. J., Sivasithamparam, K., \& Jones, R. A. C. (2010b). Comparison of the coat protein genes of Lettuce big-vein associated virus isolates from Australia with those of isolates from other continents. Archives of Virology, 155, 765-770.

Maekawa, K., Sasaya, T., Fujii, H., Ishikawa, K., Kanto, T., Iwamoto, Y., \& Aino, M. (2004). The effect of growth temperature on big-vein symptom and serological detection of Mirafiori lettuce virus and Lettuce big-vein virus in lettuce. Japanese Journal of Phytopathology, 70, 320-322.

Navarro, J. A., Botella, F., Maruhenda, A., Sastre, P., Sánchez-Pina, M. A., \& Pallas, V. (2004). Comparative infection progress analysis of Lettuce big-vein virus and Mirafiori lettuce virus in lettuce crops by developed molecular diagnosis techniques. Phytopathology, 94, 470-477.

Navarro, J. A., Botella, F., Maruhenda, A., Sastre, P., Sanchez-Pina, M. A., \& Pallas, V. (2005). Identification and partial characterisation of Lettuce big-vein associated virus and Mirafiori lettuce big-vein virus in common weeds found amongst Spanish lettuce crops and their role in lettuce big-vein disease transmission. European Journal of Plant Pathology, 113, 25-34.

Navarro, J. A., Torok, V. A., Vetten, H. J., \& Pallas, V. (2005). Genetic variability in the coat protein genes of lettuce big-vein associated virus and Mirafiori lettuce big-vein virus. Archives of Virology, 150, 681-694.

Ochoa-Martínez, D. L., Alfonsina-Hernández, J., Sánchez-Escudero, J., Rodríguez-Martínez, D., \& Vera-Graziano, J. (2014). First reports of Lettuce big-vein associated (Varicosavirus) infecting lettuce in Mexico. Plant Disease, 98, 573.

Opatovsky, I., Elbaz, M., Avraham, L., Mordechai-Lebiush, S., Dombrovsky, A., \& Tsror (Lahkim), L. (2019). Control of lettuce bigvein disease by application of fungicides and crop covers. Plant Pathology, 68, 790-795.

Opatovsky, I., Elbaz, M., Tsror (Lahkim), L., Mordechai-Lebiush, S., \& Dombrovsky, A. (2019). First report of lettuce big vein disease caused by Olpidium spp., Mirafiori lettuce big-vein virus, and lettuce big-vein associated virus in Israel. Plant Disease, 103, 779. https://doi.org/10. 1094/pdis-09-18-1585-pdn

Rochon, D. A. (2009). Fungal transmission of plant viruses. Current Protocols in Microbiology, 12, 16B-4, 1-17.
Roggero, P., Ciuffo, M., Vaira, A. M., Accotto, G. P., Masenga, V., \& Milne, V. (2000). An Ophiovirus isolated from lettuce with big-vein symptoms. Archives of Virology, 145, 2629-2642.

Roggero, P., Lot, H., Souche, S., Lenzi, R., \& Milne, R. G. (2003). Occurrence of Mirafiori lettuce virus and Lettuce big-vein virus in relation to development of big-vein symptoms in lettuce crops. European Journal of Plant Pathology, 109, 261-267.

Salem, N., Mansour, A., \& Badwan, H. (2012). Identification and partial characterization of tomato spotted wilt virus on lettuce in Jordan. Journal of Plant Pathology, 94(2), 431-435.

Sanches, M. M., Krause-Sakate, R., \& Pavan, M. A. (2008). Sequence diversity in the coat protein gene of Lettuce big-vein associated virus and Mirafiori lettuce big-vein virus infecting lettuce in Brazil. Summa Phytopathologica, 34, 175-177.

Sasaya, T., Ishikawa, K., \& Koganezawa, H. (2001). Nucleotide sequence of the coat protein gene of Lettuce big-vein virus. Journal of General Virology, 82, 1509-1515.

Sasaya, T., Ishikawa, K., Kuwata, S., \& Koganezawa, H. (2005). Molecular analysis of coat protein coding region of tobacco stunt virus shows that it is a strain of Lettuce big-vein virus in the genus Varicosavirus. Archives of Virology, 150, 1013-1021.

Sasaya, T., \& Koganezawa, H. (2006). Molecular analysis and virus transmission tests place Olpidium virulentus, a vector of Mirafiori lettuce big-vein virus and Tobacco stunt virus, as a distinct species rather than a strain of Olpidium brassicae. Journal of General Plant Pathology, 72, 20-25.

Sasaya, T., Kusaba, S., Ishikawa, K., \& Koganezawa, H. (2004). Nucleotide sequence of RNA2 of Lettuce big-vein virus and evidence for a possible transcription termination/initiation strategy similar to that of rhabdoviruses. Journal of General Virology, 85, 2709-2717.

Thompson, J. D., Gibson, T. J., Plewniak, F., Jeanmougin, F., \& Higgins, D. G. (1997). The CLUSTALX windows interface; flexible strategies for multiple sequence alignment aided by quality analysis tools. Nucleic Acids Research, 25, 4876-4882.

van der Wilk, F., Dullemans, A. M., Verbeek, M., \& van den Heuvel, J. F. (2002). Nucleotide sequence and genomic organization of an ophiovirus associated with lettuce big-vein disease. Journal of General Virology, 83, 2869-2877.

Verbeek, M., Dullemans, A. M., van Bekkum, P. J., \& van der Vlugt, R. A. A. (2013). Evidence for Lettuce big-vein associated virus as the causal agent of a syndrome of necrotic rings and spots in lettuce. Plant Pathology, 62, 444-451.

Walsh, J. A. (1994). Effects of some biotic and abiotic factors on symptom expression of lettuce big-vein virus in lettuce (Lactuca sativa). Journal of Horticultural Science, 69, 21-28.

Westerlund, F. V., Campbell, R. N., \& Grogan, R. G. (1978). Effect of temperature on transmission, translocation, and persistence of the lettuce big-vein agent and big-vein symptom expression. Phytopathology, 68, 921-926.

Zink, F. W., \& Grogan, K. (1954). The interrelated effects of big vein and market price on the yield of head lettuce. Plant Disease Reporter, 38 , 844-846.

How to cite this article: Salem N, Odeh S, Muslem MA,

Tahzima R. Occurrence and partial genetic characterisation of Lettuce big-vein associated virus and Mirafiori lettuce big-vein virus infecting lettuce in Jordan. Ann Appl Biol. 2020;1-11. https://doi.org/10.1111/aab.12595 